\title{
FINANCIAL ANALYSIS OF PERFORMANCE INDICATORS AND WAYS OF ACCOUNTING AND AUDIT IMPROVEMENT OF PRODUCTION STOCKS AT THE WAREHOUSES OF PJSC «DNEPROSPETSSTAL»
}

\author{
O. Hamova, I. Kozachok \\ Zaporizhzhya National University \\ Ukraine, 69000, Zaporozhye, Zhukovsky St. 66 \\ gamova5oxana@gmail.com, irina1kozachek@gmail.com \\ ORCID ID: 0000-0002-9752-6900, ORCID ID: 0000-0002-0489-9696
}

Key words:

accounting, audit, production inventories, warehouse, enterprise.

\begin{abstract}
During the writing of the article, the authors achieved the goal, namely, to develop scientifically sound ways of improving of accounting and auditing at the stock of PJSC «Dniprospetsstal».

The algorithm of analytical accounting forming for additional properties of inventories in the warehouses of PJSC «Dniprospetsstal» and information of the analysis of availability of inventories in the warehouse and the cost estimate of the composition of inventories in the prices of the nomenclature are offered. On the timeliness and correctness of the documentary registration of operations on the receipt of inventories to the warehouse of PJSC «Dniprospetsstal» depend on the accuracy of the attribution of their value to the cost of production, the rationality of estimation of work in progress. All these suggestions of forming analytical accounting for additional inventory properties and improving the documentation of stock availability and inventory make it possible to obtain more information from fewer documents, which, in turn, increases their informative and analytical nature.

According to the results of the research, the methodology for carrying out the audit of inventory at the warehouses of PJSC «Dniprospetsstal» and the working documents of the auditor, which can be used at the enterprise for conducting better audit of production inventories, are proposed. The purpose of drafting the working documents for the audit of inventories at the warehouses of PJSC «Dniprospetsstal» is the need to form audit evidence to substantiate the audit opinion, as well as to confirm the facts of the audit in accordance with the legislative and standard (regulatory) requirements.

The practical implementation of the proposed recommendations for improving inventory accounting and auditing will help to improve the effectiveness of management decisions regarding the use of inventory by business entities.
\end{abstract}

\section{ФІНАНСОВИЙ АНАЛІЗ ПОКАЗНИКІВ ДІЯЛЬНОСТІ ТА ШЛЯХИ ВДОСКОНАЛЕННЯ ОБЛІКУ ТА АУДИТУ ВИРОБНИЧИХ ЗАПАСІВ НА СКЛАДАХ ПРАТ «ДНІПРОСПЕЦСТАЛЬ»}

Гамова О. В., Козачок І. А.

Запорізький національний університет

Україна, 69000, м. Запоріжжя, вул. Жуковського 66

Ключові слова:

облік, аудит, виробничі запаси, склад, підприємство.
В ході написання статті авторами була досягнута мета, а саме проведено фінансовий аналіз показників діяльності та розроблені науково обгрунтовані шляхи вдосконалення обліку та аудиту виробничих запасів на складі підприємства ПрАТ «Дніпроспецсталь».

Запропоновано алгоритм формування аналітичного обліку за додатковими властивостями виробничих запасів на складах ПрАТ «Дніпроспецсталь» та відомості аналізу доступності виробничих запасів на складі та вартісної оцінки складу виробничих запасів в цінах номенклатури. Від своєчасності та правильності документального оформлення операцій із надходження виробничих запасів на склад ПрАТ «Дніпроспецсталь» залежать достовірність віднесення їх вартості на витрати виробництва, раціональність оцінки залишків незавершеного виробництва. Усі зазначені пропозиції щодо формування аналітичного обліку за додатковими властивостями запасів та вдосконалення документального оформлення наявності та надходження виробничих запасів дають можливість отримати більше інформації з меншої кількості документів, що, своєю чергою, впливає на підвищення їх інформативності та аналітичності.

За результатами дослідження запропоновано методика проведення аудиту оцінки виробничих запасів на складах ПрАТ «Дніпроспецсталь» та робочі документи аудитора, які можна бути використовувати на підприємстві для проведення більш якісної аудиторської перевірки виробничих запасів. Мета 
складання робочих документів 3 аудиту виробничих запасів на складах ПрАТ «Дніпроспецсталь» полягає в необхідності формування аудиторських доказів для обгрунтування аудиторської думки (висновку), а також для підтвердження фактів здійснення аудиту відповідно до законодавчих та стандартних (нормативних) вимог.

Застосування на практиці запропонованих рекомендацій з удосконалення обліку та аудиту виробничих запасів на складі сприятиме підвищенню ефективності управлінських рішень щодо використання виробничих запасів суб'єктами господарювання.

\section{Introduction}

To carry out economic activities by enterprises of all forms of ownership and sectors of the economy the production stocks are used, which are the most important and significant part of the assets of the enterprise. This requires the creation of a qualitatively new system of material resources management, and primarily, inventories, which includes accounting and auditing, because in the formation of the cost of finished products inventories occupy a special place not only in the property but also in the cost structure of the enterprise. Inventory accounting in the warehouse of an industrial enterprise, which is properly organized, high-quality awareness of their availability and movement, is essential in the management of production activities of each enterprise and in the control of storage of tangible assets in the form of inventories.

\section{Analysis of recent research and publications}

A significant contribution to the development of theoretical and methodological principles of financial analysis of indicators of activity, accounting and audit of inventories of the enterprise was made by domestic scientists: G. M. Azarenkova, B. B. Babich, N. O. Bondarenko, T. A. Butynets, F. F. Butynets,
O. Р. Гаценко, M. I. Kamlik, S. F. Golov, M. I. Dolzhansky, V. P. Zavgorodniy, M. V. Kuzhelny, L. P. Kulakovskaya, V. G. Lovinska, J.M. Petrovich, M. S. Pushkar, I. I. Sahartseva, V. V. Sopko, N. V. Chebanova, V. Ye. Shvets and others. Problems of methods of accounting of production stocks were paid attention by foreign scientists: M. Gillingham, M. Linders, A. N. Sterligova, J. R. Stoke, D. Waters, J. Schreibfeder and others. Paying tribute to the scientific achievements of domestic and foreign scientists, it should be noted that the issues of accounting and auditing of inventories in the warehouse of the enterprise require further research.

\section{Setting of the objectives}

The purpose of the study is to conduct a financial analysis of performance indicators and develop scientifically sound ways to improve the accounting and audit of inventories in the warehouse of PJSC "Dniprospetsstal".

The main activity of PJSC "Dniprospetsstal" and its subsidiaries is the development, production and sale of metal products, which is in demand in more than 60 countries. The main markets are Ukraine, CIS countries, EU countries and more.

The main performance indicators of PJSC "Dniprospetsstal" and its subsidiaries for 2016-2019. are presented in table 1 .

Table 1. The main performance indicators of PJSC "Dniprospetsstal" and its subsidiaries for 2016-2019.

\begin{tabular}{|c|c|c|c|c|c|c|c|}
\hline \multirow[t]{2}{*}{ № } & \multirow[t]{2}{*}{ indicators } & \multicolumn{4}{|c|}{ As of 31.12} & \multicolumn{2}{|c|}{ Change in 2019 until 2018} \\
\hline & & 2016 & 2017 & 2018 & 2019 & absolute & relative, $\%$ \\
\hline 1. & $\begin{array}{l}\text { Income from sales of metal } \\
\text { products, thousand UAH }\end{array}$ & 6319107 & 8164952 & 9616951 & 8280234 & $(1336717)$ & $-13,9$ \\
\hline 2. & $\begin{array}{l}\text { Volume of sold metal } \\
\text { products, tons }\end{array}$ & 147297 & 165519 & 157971 & 147544 & $(10427)$ & $-6,6$ \\
\hline 3. & $\begin{array}{l}\text { Cost of goods sold, } \\
\text { thousand UAH }\end{array}$ & $(5543947)$ & $(7151107)$ & $(9103504)$ & $(7815501)$ & $(1288003)$ & $-14,1$ \\
\hline 4. & Gross profit, thousand UAH & 775160 & 1013845 & 513447 & 464733 & $(48714)$ & $-9,5$ \\
\hline 5. & $\begin{array}{l}\text { Net profit / (loss), thousand } \\
\text { UAH }\end{array}$ & $(403651)$ & 61023 & $(428452)$ & 78131 & 506583 & 118,2 \\
\hline \multirow[t]{3}{*}{6.} & $\begin{array}{l}\text { Exports, thousand UAH, } \\
\text { incl. }\end{array}$ & 3921779 & 5145257 & 5970744 & 5087457 & $(883287)$ & $-14,8$ \\
\hline & Foreign countries & 2581821 & 3507617 & 4242059 & 3295773 & $(946286)$ & $-22,3$ \\
\hline & CIS countries & 1339958 & 1637640 & 1728685 & 1791684 & 62999 & 3,6 \\
\hline 7. & $\begin{array}{l}\text { Share of exports in total } \\
\text { industrial output, } \%\end{array}$ & 62,1 & 63,0 & 62,1 & 61,4 & $-0,7$ & $-1,0$ \\
\hline 8. & $\begin{array}{l}\text { Delivery of metal products, } \\
\text { thousand UAH }\end{array}$ & 6305154 & 8149922 & 9616361 & 8281858 & $(1334503)$ & $-13,9$ \\
\hline 9. & $\begin{array}{l}\text { Volume of production of } \\
\text { metal products, tons }\end{array}$ & 147398 & 165576 & 158025 & 148299 & (9726) & $-6,2$ \\
\hline
\end{tabular}

As for January 1, 2020, according to the results of 2019, PJSC Dniprospetsstal and its subsidiaries received a net income from the sale of metal products in the amount of
UAH 8280234 thousand, which is UAH 1336717 thousand or $13.9 \%$ less than the corresponding figure in 2018. This change in net sales occurred due to: 
- decrease in prices for finished products, which caused a decrease of 902209 thousand UAH. and was due to trends in the market of metal products of Ukraine and the world, as well as the strengthening of the national currency to foreign currencies;

- reduction of the number of orders from customers due to intensification of competition from foreign metal producers, which led to a decrease in the physical volume of manufactured and sold products by $6.6 \%$ and caused a negative change in net income by 434508 thousand UAH. Dynamics of changes in the structure of assets and liabilities of the balance sheet of PJSC "Dniprospetsstal" for 2016-2019. we present graphically in Figures 1 - 2.

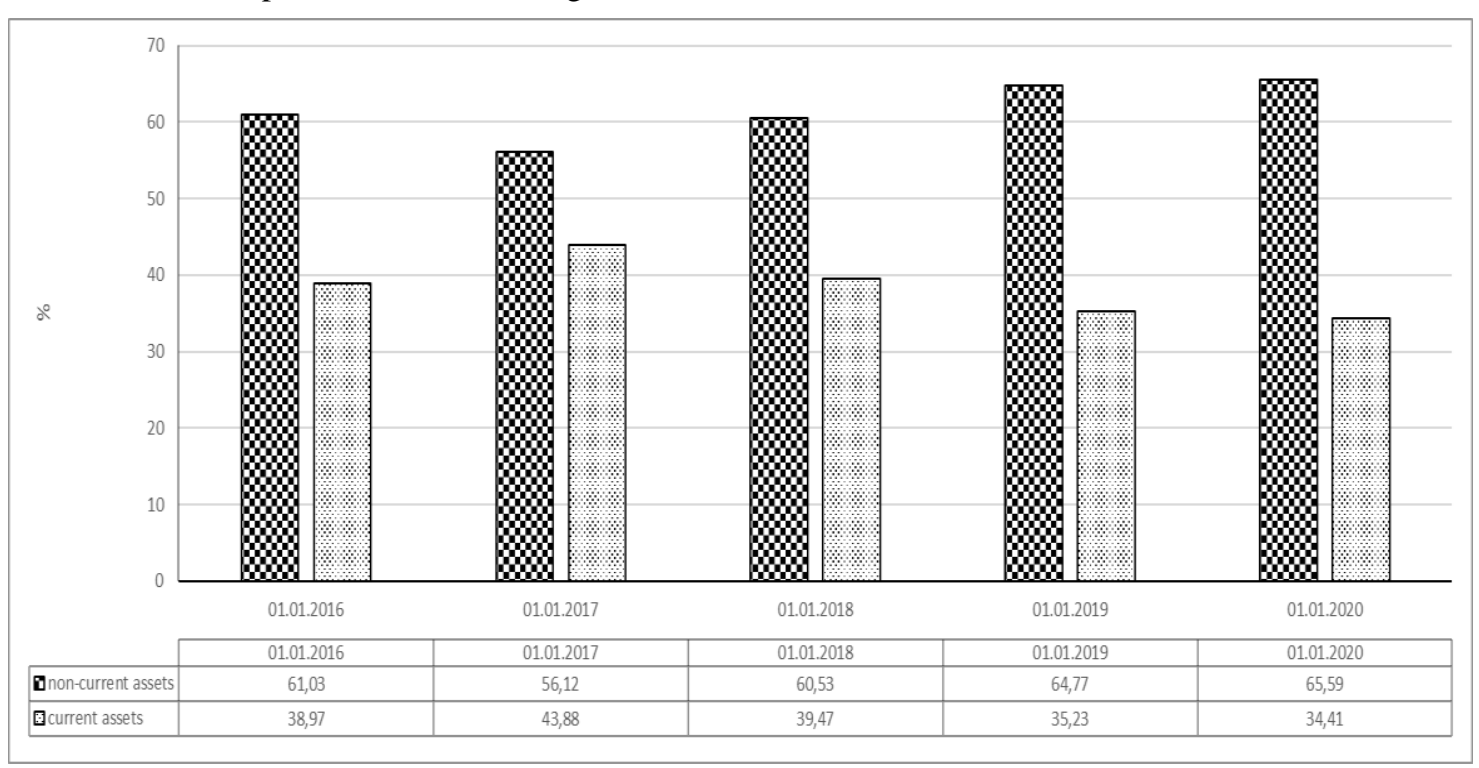

Figure 1. Dynamics of changes in the asset structure of the Balance Sheet of PJSC Dniprospetsstal for 2016-2019

As of 31.12.2019 current assets of the enterprise exceeded current liabilities by UAH 249638 thousand compared to 2018 - by UAH 740,713 thousand, in turn the book value of the company's equity amounted to UAH 12,57788 thousand.

Decrease in the book value of assets as of December 31, 2019 occurred primarily due to:

- decrease in market prices for inventories, which in turn led to a decrease in monetary balances of work in progress and finished goods in monetary terms;
- reduction of the balance of receivables for products, goods, works, services, due to a decrease in sales due to oversaturation of the metal products market.

The main change in the structure of non-current and current assets was related to the transfer of long-term deposits to the short-term part due to the expiration date in April 2120. The decrease in accounts payable for goods, works and services was due to lower prices for raw materials and supplies.

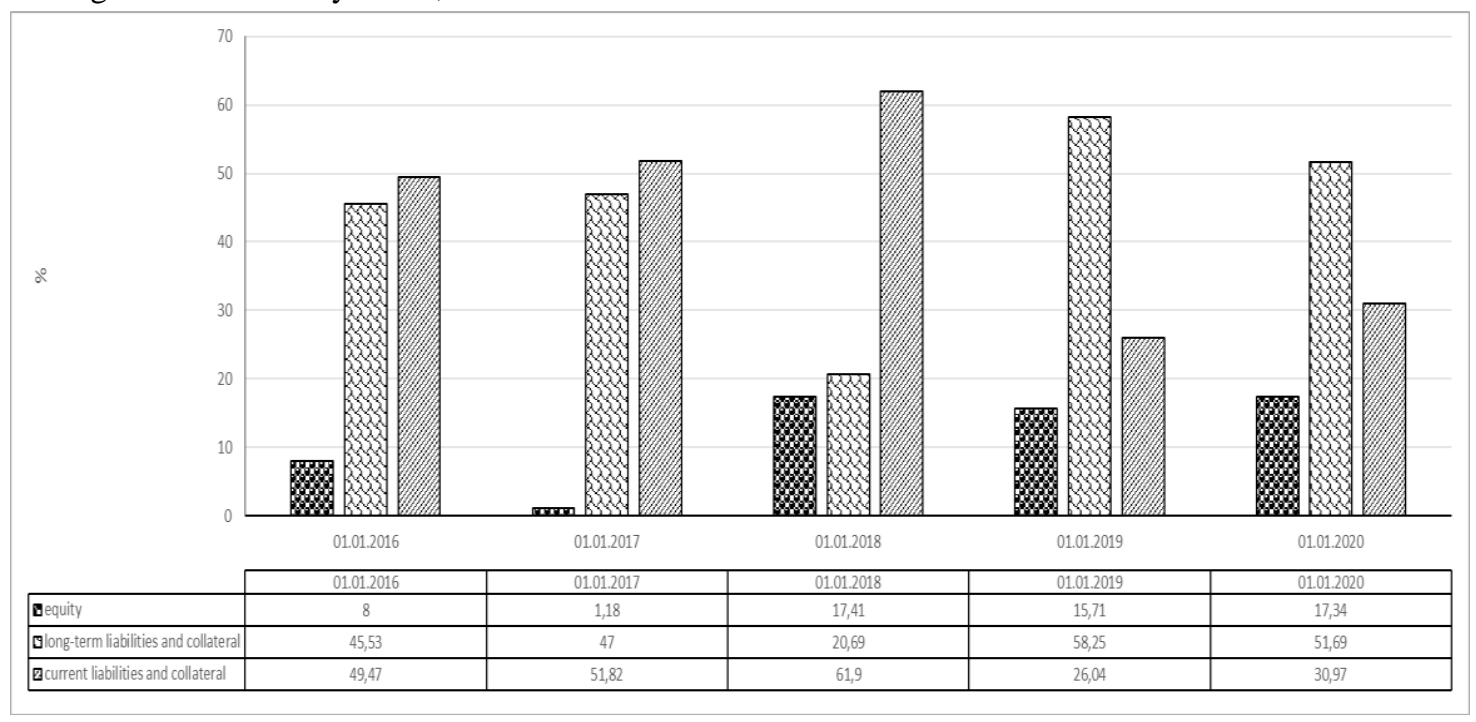

Figure 2. Dynamics of changes in the structure of liabilities of the balance sheet of PJSC "Dniprospetsstal" for 2016-2019.

The assessment of the property status of PJSC "Dniprospetsstal" was carried out on the basis of analytical grouping of assets and liabilities of the balance sheet for 2016-2019. The results are presented in table 2. 
Table 2. Dynamics of changes in the property status of PJSC "Dniprospetsstal" for 2016-2019

\begin{tabular}{|c|c|c|c|c|c|}
\hline $\begin{array}{l}\text { № in } \\
\text { order }\end{array}$ & Indicator & $\begin{array}{l}\text { On } 31.12 \text {. } \\
2016\end{array}$ & $\begin{array}{c}\text { On } \\
31.12 \text {. } \\
2017\end{array}$ & $\begin{array}{l}\text { On } 31.12 \text {. } \\
2018\end{array}$ & $\begin{array}{c}\text { On } \\
31.12 \text {. } \\
2019\end{array}$ \\
\hline 1 & $\begin{array}{l}\text { The total amount of economic resources at the } \\
\text { disposal of the enterprise }\end{array}$ & $\begin{array}{l}5941408,0 \\
0\end{array}$ & $\begin{array}{c}7945339,0 \\
0\end{array}$ & $\begin{array}{l}8121825,0 \\
0\end{array}$ & 7253907,00 \\
\hline 2 & The share of non-current assets in assets & 0,56 & 0,61 & 0,65 & 0,66 \\
\hline 3 & The share of fixed assets in assets & 0,55 & 0,60 & 0,61 & 0,64 \\
\hline 4 & The share of fixed assets in non-current assets & 0,98 & 0,99 & 0,94 & 0,98 \\
\hline 5 & Depreciation rate of fixed assets & 0,08 & 0,02 & 0,02 & 0,09 \\
\hline 6 & Coefficient of suitability & 0,92 & 0,98 & 0,98 & 0,91 \\
\hline 7 & $\begin{array}{l}\text { The share of current assets in the assets of the } \\
\text { enterprise }\end{array}$ & 0,44 & 0,39 & 0,35 & 0,34 \\
\hline 8 & The share of working capital in current assets & $-0,18$ & $-0,57$ & 0,26 & 0,10 \\
\hline 9 & The share of inventories in current assets & 0,36 & 0,4 & 0,49 & 0,45 \\
\hline 10 & $\begin{array}{l}\text { The share of working capital in covering } \\
\text { inventories and costs }\end{array}$ & $-0,5$ & $-1,43$ & 0,53 & 0,22 \\
\hline
\end{tabular}

Examining the interdependence of liquidity and solvency indicators of PJSC "Dniprospetsstal", it should be noted that liquidity is a less dynamic category than solvency. Analysis of the solvency indicators of PJSC
"Dniprospetsstal" showed that the company does not have the ability to meet external obligations. Not all of solvency ratios for the period of 2016-2019 meet the normative values, but at the end of 2019 they have a positive trend.

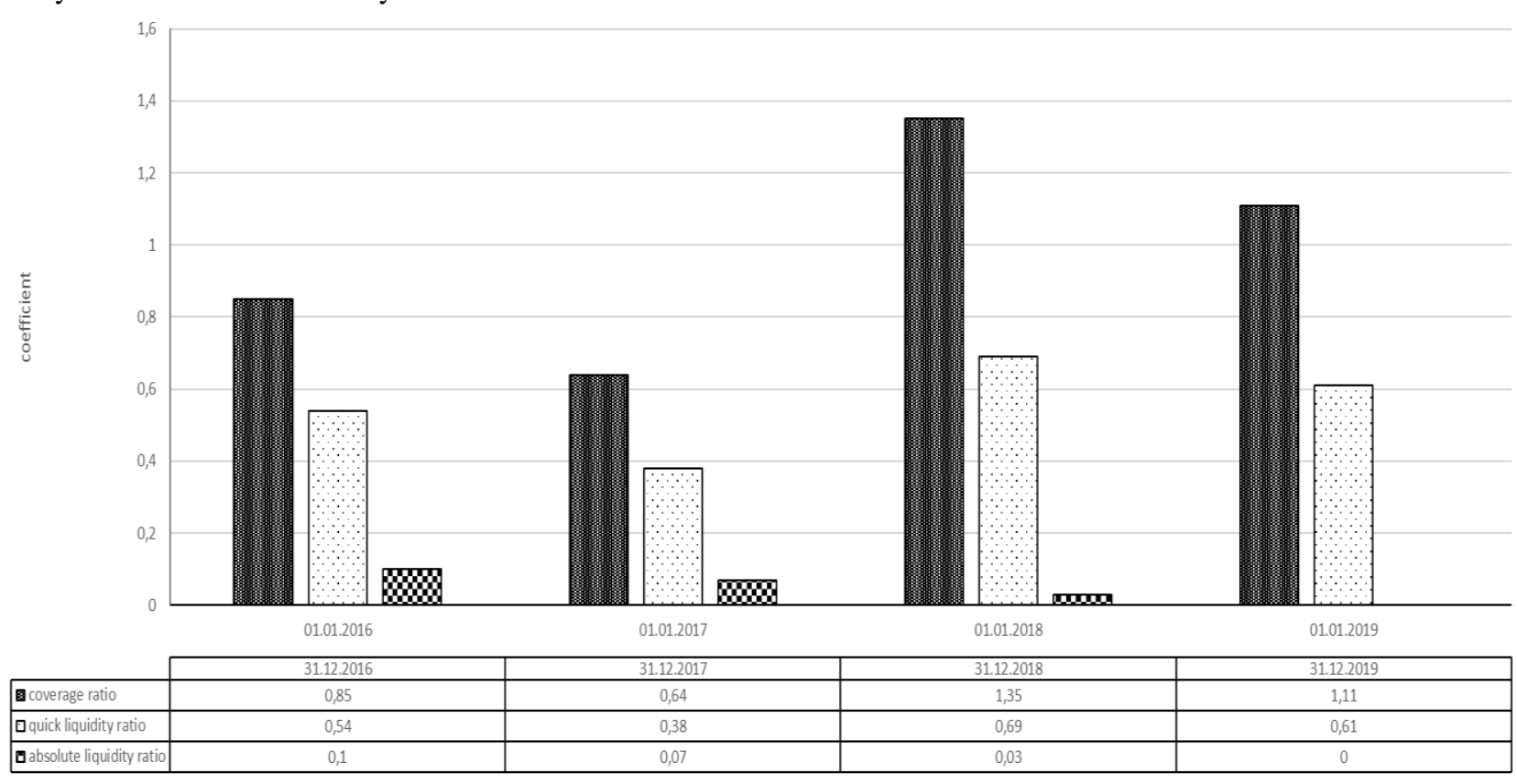

Figure 3. Dynamics of changes in liquidity indicators of PJSC "Dniprospetsstal" for 2016-2019 


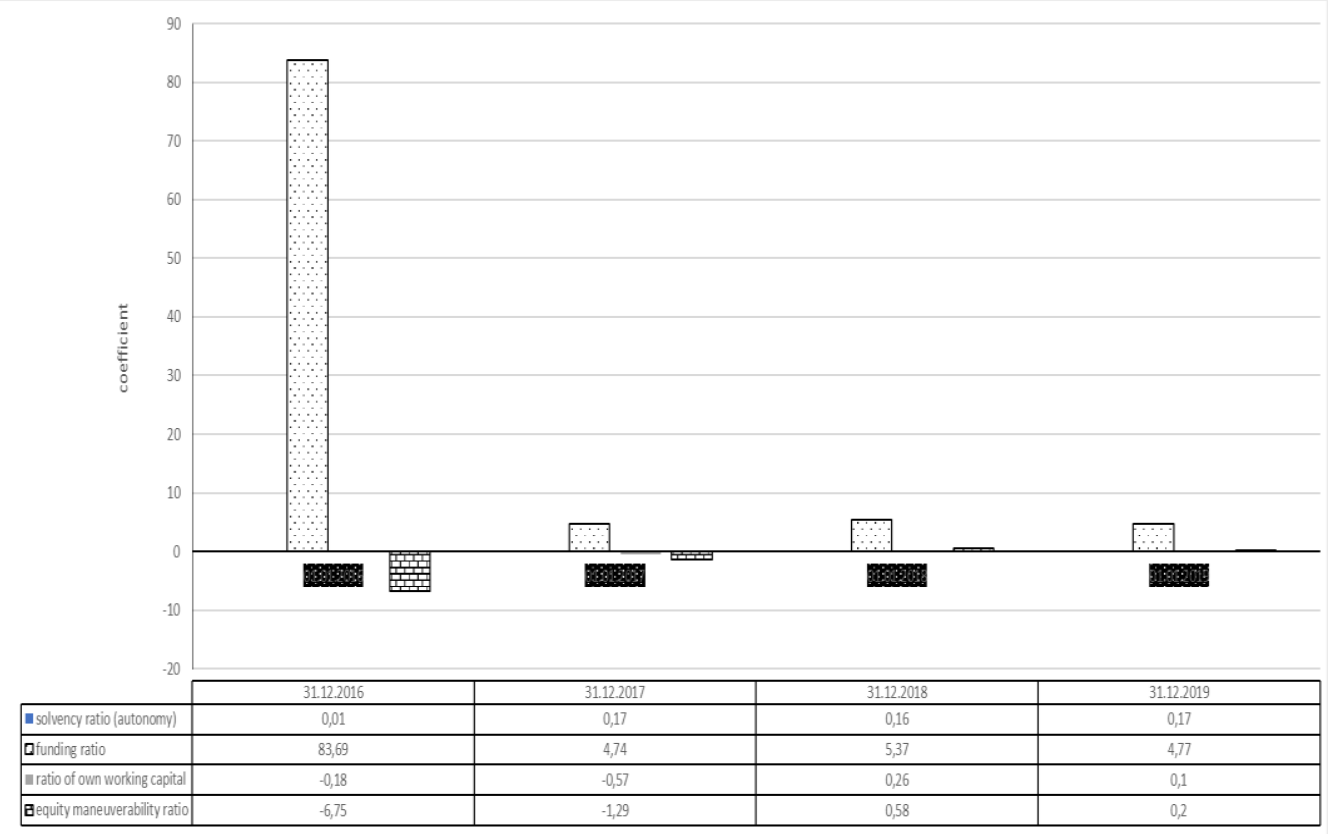

Figure 4. Dynamics of solvency indicators of PJSC "Dniprospetsstal" for 2016-2019

The provision of the company with its own working capital is evidenced by the security ratio, which had a negative value during 2016 - 2017, which indicates a deficit of working capital, but as of 31.12.2018 this ratio at PJSC "Dniprospetsstal" was 0.26. That is, the company eliminated the deficit of its own working capital. But the balance sheet structure of PJSC "Dniprospetsstal" should be considered unsatisfactory, and the company - insolvent because there is a reason - the fulfillment of one of the conditions:

- current liquidity ratio at the end of 2019. has a value of less than 2;

- the ratio of own working capital at the end of the reporting period is less than 0.1 (at PJSC "Dniprospetsstal" it was 0.26 as of 31.12.2018).
The equity maneuverability ratio was 6.75 with a minus sign at the end of 2016. and 1.29 with a minus sign at the end of 2017, is outside the norm, but tends to increase at the end of 2019. amounted to 0.2. Thus, it can be noted that as of 31.12.2019. The situation at Dniprospetsstal PJSC has improved, as evidenced by liquidity and solvency indicators.

5. Analysis of business activity indicators of PJSC "Dniprospetsstal" allows you to assess the internal and external state of the enterprise, determine the level of profitability and prospects for its development, to investigate the efficiency of production and financial resources (Fig. 5).

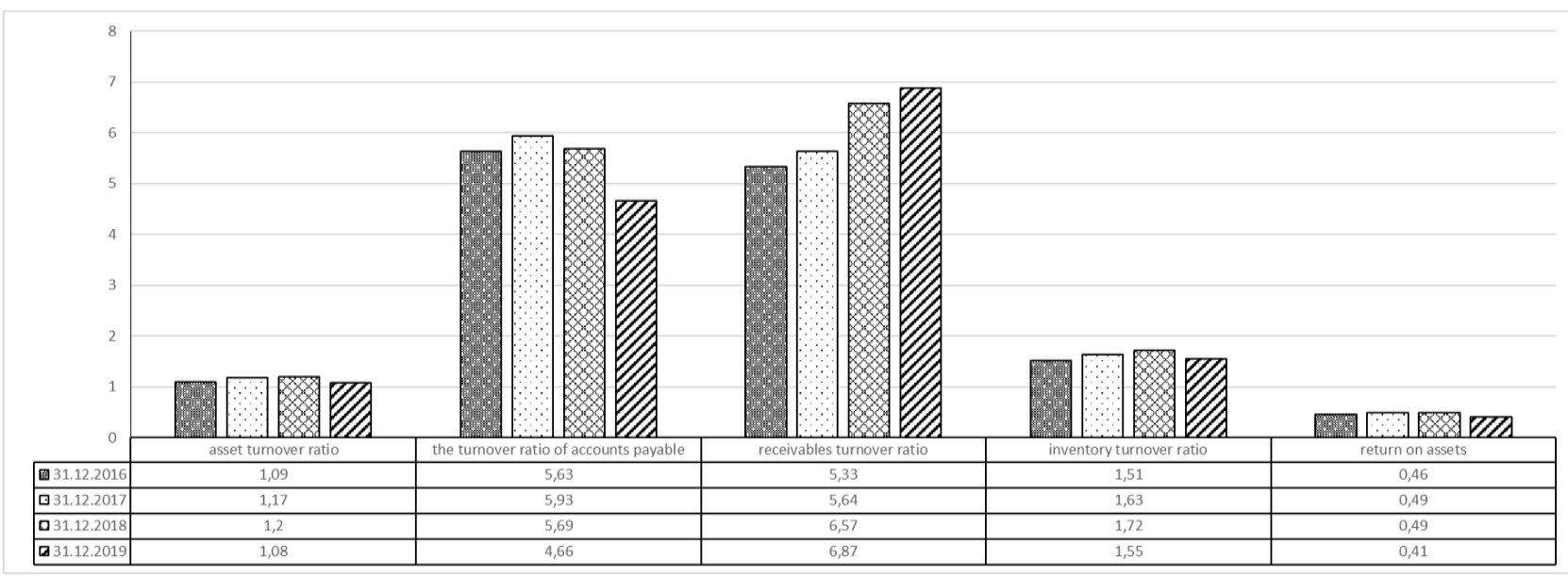

Figure 5. Dynamics of business activity indicators of PJSC Dniprospetsstal for the period of 2016-2019

Analysis of business activity of PJSC "Dniprospetsstal" showed that the coefficients of business activity have a positive trend, but analyzing the financial condition, which is calculated on the basis of financial statements of
PJSC "Dniprospetsstal" for the period 2016-2018, we can say that the industrial enterprise is unprofitable.

Accounting of inventories in a large metallurgical enterprise is a complex system that has many nuances and features. 
Documenting the receipt, availability and use of inventories is a very responsible process, especially at PJSC "Dniprospetsstal". Despite the fact that the legislative base of Ukraine has a significant number of documents governing the accounting and reflection of information about them in the reporting, it is necessary to develop and improve primary accounting documents that will disclose and record the features of inventory accounting at PJSC "Dniprospetsstal »And provide the necessary information for both accounting systems and systems for control and operational management of the movement of inventories, which will improve the quality of accounting work.

The data specified in the primary accounting documents are systematized in the accounts, in the registers of analytical and synthetic accounting. At PJSC "Dniprospetsstal" it is allowed to compile primary documents in paper and electronic form. In general, the process of primary inventory accounting is time consuming.

For operative accounting of production stocks at PJSC "Dniprospetsstal" it is not enough to have information about their total cost, and it is not enough to know their list and quantity. At the enterprise of PJSC "Dniprospetsstal" several main and auxiliary warehouses, with assets in the form of inventories, are in different warehouses. To increase the efficiency and accuracy of accounting, it is necessary to know the quantitative distribution of inventories in terms of warehouses of the enterprise. Fixation in the accounting system of additional information will make it possible to create analytical sections of accounting. Analytical accounting for additional properties of production stocks imposes obligations on registration of business transactions in the accounting of PJSC "Dniprospetsstal" and includes:

- at receipt, specify the value of these properties upon transaction;

- at disposal to specify analytical parameters in accordance with the balances available in warehouses;

- if the value of the analytical parameter for inventories is changed, it is necessary to record such transactions in the system, even if it is not related to the actual movement of inventories. For example, if inventories are transferred from one account to another.

To account for inventories in the warehouses of PJSC "Dniprospetsstal" you can offer the following set of sections of analytical accounting:
- organization - inventories are available to a particular organization;

- warehouse - production stocks are tied to the city of storage or, in some cases, to the counterparty;

- nomenclature - for production stocks a name card must be established;

- additional characteristics and series - describe the nomenclature position;

- quality - for inventories can be set quality, which describes its suitability;

- order - inventories can be reserved for the order;

- accounting account;

- tax purpose - the purpose of use in terms of tax accounting.

The formation of analytical accounting for additional properties of inventories in the warehouses of PJSC "Dniprospetsstal" is presented in Figure 6.

To form analytical accounting for additional properties of inventories in the warehouses of PJSC "Dniprospetsstal" it is necessary:

- to make a choice of primary documents (from the approved standard forms or development of own) by means of which operations on the movement of production stocks will be made out;

- to ensure timely documentation of operations on the movement of inventories;

- in accordance with the needs of accounting and management functions, to group production stocks in warehouses;

- to indicate in the Order on accounting policy methodical receptions which will reflect a technique of accounting of production stocks of the enterprise;

- to conclude agreements on full material responsibility of the persons who will be responsible for preservation of production stocks;

- to determine the accounting sector and its responsibilities for accounting for transactions with inventories in warehouses.

The process of documenting production stocks in the warehouse of PJSC "Dniprospetsstal" should be divided into stages: receipts (accounting); availability of values; spending (disposal); generalization of information (until the moment of transfer to accounting). 

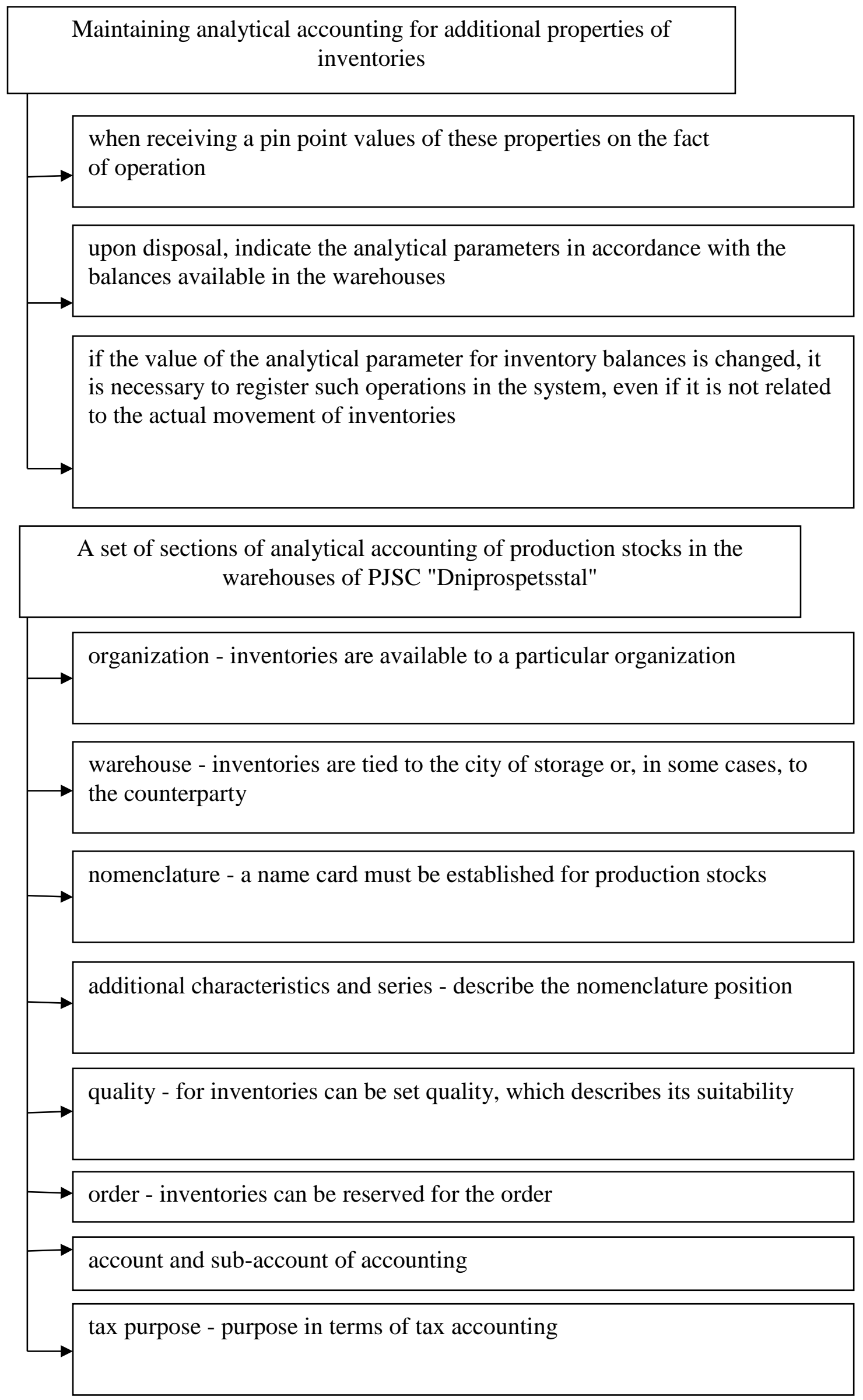

Figure 6. Formation of analytical accounting for additional properties of production stocks in warehouses of PJSC "Dniprospetsstal" 
At each stage of registration of information there should be a minimum number of unified documents that accumulate data on the movement of inventories. Table 34 presents the proposed documents, which analyze the availability of inventories in the warehouses of PJSC "Dniprospetsstal" and the valuation of the warehouse in the prices of the nomenclature.

Table 3. The proposed statement of the availability analysis of production stocks in a warehouse availability PJSC "Dniprospetsstal", in tons
The timeliness and correctness of the documentation of operations on the receipt of production stocks in the warehouse of PJSC "Dniprospetsstal" depend on the reliability of their value to the cost of production, the rationality of estimating the balance of work in progress.

\begin{tabular}{|c|c|c|c|c|c|c|}
\hline warehouse & & & & & & \\
\hline Nomenclature & 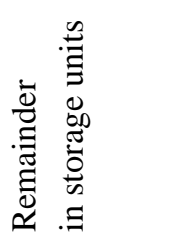 & 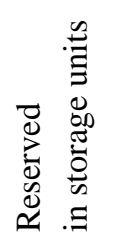 & 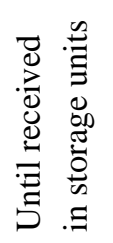 & 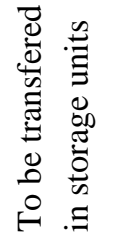 & 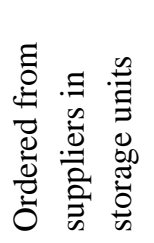 & 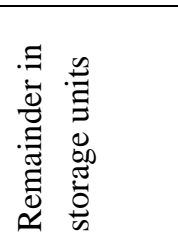 \\
\hline warehouse № 7 & 190,000 & - & - & - & - & 190,000 \\
\hline 201.1 .07 .15 & 20,000 & - & - & - & - & 20,000 \\
\hline 201.1 .07 .16 & 70,000 & - & - & - & - & 70,000 \\
\hline 201.1 .07 .17 & 100,000 & - & - & - & - & 100,000 \\
\hline Main warehouse & 7664,000 & - & - & - & - & 7664,000 \\
\hline 201.1 .01 .12 & 70,000 & - & - & - & - & 70,000 \\
\hline 201.1 .01 .42 & 4527,000 & - & - & - & - & 4527,000 \\
\hline 201.1 .01 .45 & 297,000 & - & - & - & - & 297,000 \\
\hline 201.1 .01 .47 & 5,000 & - & - & - & - & 5,000 \\
\hline 201.1 .01 .52 & 30,000 & - & - & - & - & 30,000 \\
\hline 201.1 .01 .56 & 70,000 & - & - & - & - & 70,000 \\
\hline 201.1 .01 .57 & 300,000 & - & - & - & - & 300,000 \\
\hline 201.1 .01 .62 & 550,000 & - & - & - & - & 550,000 \\
\hline 201.1 .01 .64 & 20,000 & - & - & - & - & 20,000 \\
\hline 201.1 .01 .71 & 1,000 & - & - & - & - & 1,000 \\
\hline 201.1 .01 .72 & 748,000 & - & - & - & - & 748,000 \\
\hline 201.1 .01 .73 & 100,000 & - & - & - & - & 100,000 \\
\hline 201.1 .01 .78 & 2,000 & - & - & - & - & 2,000 \\
\hline 201.1 .01 .85 & 30,000 & - & - & - & - & 30,000 \\
\hline total & 7854,000 & - & - & - & - & 7854,000 \\
\hline
\end{tabular}

Nomenclature of production stocks, which includes the Description of nomenclature cards is an extremely important document, as in the warehouses of PJSC "Dniprospetsstal" the nomenclature of production stocks is very large. Therefore, when using electronic document management, it will be intended for quick access to the Nomenclature Card through the stock nomenclature

Table 4. The proposed statement of valuation of inventories in the prices of the nomenclature of PJSC "Dniprospetsstal"

\begin{tabular}{|c|c|c|c|c|c|c|c|c|c|}
\hline \multirow{2}{*}{$\begin{array}{c}\text { warehouse } \\
\text { nomenclature }\end{array}$} & \multicolumn{2}{|c|}{ Quantaty } & \multicolumn{2}{|c|}{$\begin{array}{l}\text { Number of } \\
\text { uninvoiced }\end{array}$} & \multirow{2}{*}{$\begin{array}{c}\text { Cost of } \\
\text { income, } \\
\text { thousand } \\
\text { UAH }\end{array}$} & \multicolumn{4}{|c|}{$\begin{array}{c}\text { In the selected type of prices } \\
\text { (thousand UAH) }\end{array}$} \\
\hline & $\begin{array}{c}\text { in } \\
\text { storage } \\
\text { units }\end{array}$ & $\begin{array}{l}\text { in } \\
\text { base } \\
\text { units }\end{array}$ & $\begin{array}{c}\text { in } \\
\text { storage } \\
\text { units }\end{array}$ & $\begin{array}{l}\text { in } \\
\text { base } \\
\text { units }\end{array}$ & & price & cost & extra & profitability \\
\hline warehouse № 7 & 190,000 & 190,000 & - & - & 559,48 & - & - & - & - \\
\hline 201.1 .07 .15 & 20,000 & 20,000 & - & - & 0,60 & - & - & - & - \\
\hline 201.1 .07 .16 & 70,000 & 70,000 & - & - & 259,41 & - & - & - & - \\
\hline 201.1 .07 .17 & 100,000 & 100,000 & - & - & 299,47 & - & - & - & - \\
\hline
\end{tabular}




\begin{tabular}{|l|c|c|c|c|c|c|c|c|c|}
\hline Main warehouse & 7664,000 & 7664,000 & - & - & 59378,73 & - & - & - & - \\
\hline 201.1 .01 .12 & 70,000 & 70,000 & - & - & 210,00 & - & - & - & - \\
\hline 201.1 .01 .42 & 4527,000 & 4527,000 & - & - & 27389,30 & - & - & - & - \\
\hline 201.1 .01 .45 & 297,000 & 297,000 & - & - & 14850,00 & - & - & - & - \\
\hline 201.1 .01 .47 & 5,000 & 5,000 & - & - & 7,50 & - & - & - & - \\
\hline 201.1 .01 .52 & 30,000 & 30,000 & - & - & 0,90 & - & - & - & - \\
\hline 201.1 .01 .56 & 70,000 & 70,000 & - & - & 6300,00 & - & - & - & - \\
\hline 201.1 .01 .57 & 300,000 & 300,000 & - & - & 187,50 & - & - & - & - \\
\hline 201.1 .01 .62 & 550,000 & 550,000 & - & - & 2038,24 & - & - & - & \\
\hline 201.1 .01 .64 & 20,000 & 20,000 & - & - & 400,00 & - & - & - & - \\
\hline 201.1 .01 .71 & 1,000 & 1,000 & - & - & 200,00 & - & - & - & - \\
\hline 201.1 .01 .72 & 748,000 & 748,000 & - & - & 715,79 & - & - & - & - \\
\hline 201.1 .01 .73 & 100,000 & 100,000 & - & - & 252,50 & - & - & - & - \\
\hline 201.1 .01 .78 & 2,000 & 2,000 & - & - & 200,00 & - & - & - & - \\
\hline 201.1 .01 .85 & 30,000 & 30,000 & - & - & 1200,00 & - & - & - & - \\
\hline 201.1 .01 .88 & 4,000 & 4,000 & - & - & 30,00 & - & - & - & - \\
\hline 201.1 .01 .93 & 900,000 & 900,000 & - & - & 5400,00 & - & - & - & - \\
\hline Total & 7854,000 & 7854,000 & - & - & 59938,21 & - & - & - & - \\
\hline
\end{tabular}

The analysis of the scientific literature makes it possible to state that in the scientific society there is no single conceptual approach to the methodology of auditing inventories. Figure 7 suggests a method of auditing the valuation of inventories in the warehouses of PJSC "Dniprospetsstal", as the valuation is closely related to all components of the method of accounting and is a prerequisite for accounting of inventories in warehouses.

Users and their information needs for the formation of a quality accounting and management system

Formation of the auditor's report on the assessment of inventories

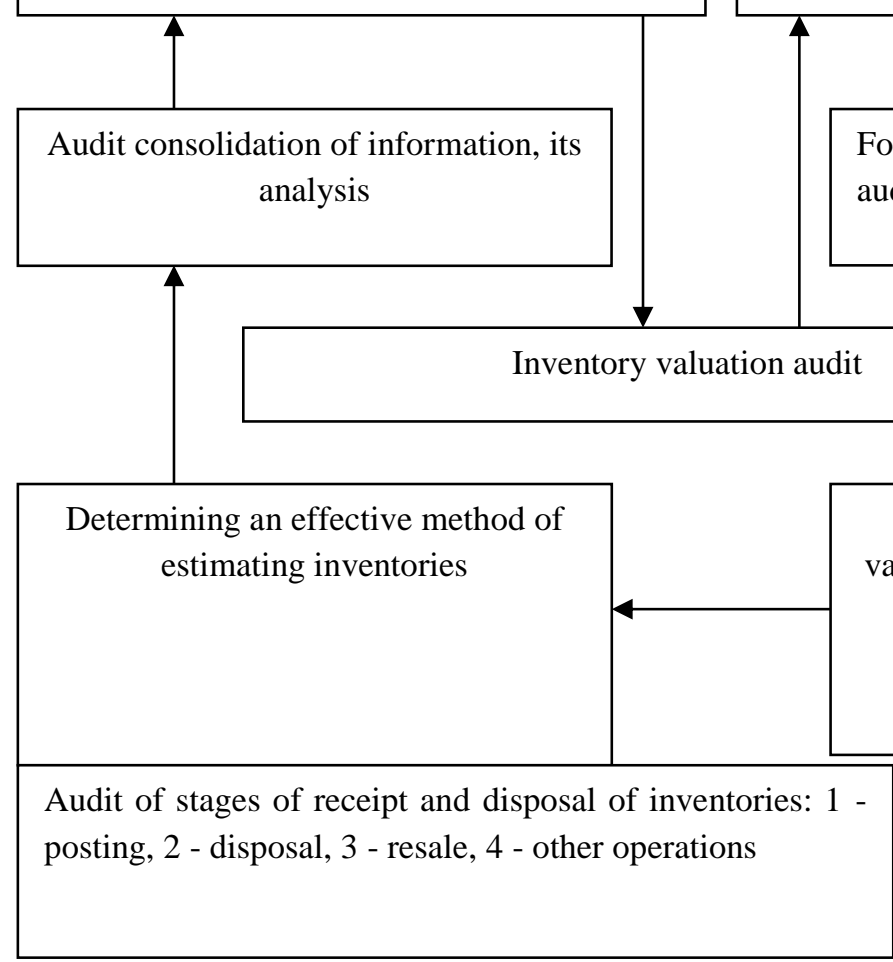

Object, subject, purpose and functions of the audit of inventories

Formation of methods for conducting an audit of inventory valuation

Audit comparisons of inventory valuation results by different methods

Figure 7 The method of conducting an audit of the assessment of production stocks in the warehouses of PJSC "Dniprospetsstal" 
The audit of current accounting of inventories in the warehouses of PJSC "Dniprospetsstal" is characterized by the processing of a large number of inventories in its operations, so to create effective document management it is necessary to develop and implement certain working documents of the auditor (Table 5 - 10).

Table 5. Auditor's working document. Comparison of these documents on the accounting of inventories and payment requirements of suppliers

\begin{tabular}{|c|c|c|c|c|c|c|c|c|c|}
\hline \multirow{2}{*}{ 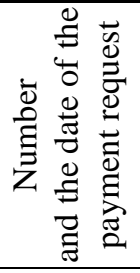 } & \multirow{2}{*}{ Provider } & \multirow{2}{*}{ Material name } & \multirow{2}{*}{$\begin{array}{l}\text { Price, } \\
\text { UAH }\end{array}$} & \multicolumn{2}{|c|}{ On demand } & \multicolumn{2}{|c|}{$\begin{array}{l}\text { According to } \\
\text { the warehouse } \\
\text { documents }\end{array}$} & \multicolumn{2}{|c|}{ Difference } \\
\hline & & & & 㤂 & 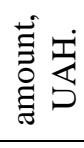 & 忐 & 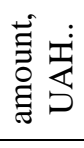 & 忐 & 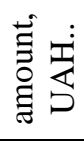 \\
\hline 1 & 2 & 3 & 4 & 5 & 6 & 7 & 8 & 9 & 10 \\
\hline
\end{tabular}

Table 6. Auditor's working document. Verification of the invoice requirement for production stocks in the warehouses of PJSC "Dniprospetsstal"

\begin{tabular}{|c|c|c|c|c|c|c|c|c|c|c|c|}
\hline \begin{tabular}{|l} 
№ \\
\end{tabular} & 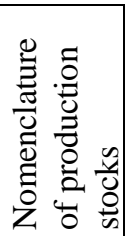 & 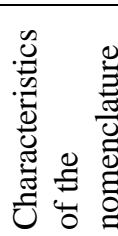 & 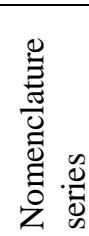 & 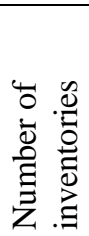 & 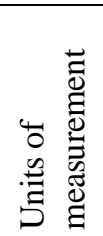 & 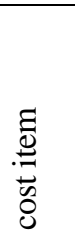 & 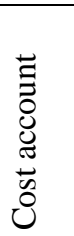 & 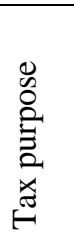 & 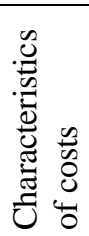 & 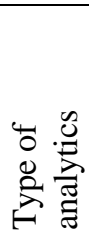 & 离 \\
\hline 1 & 2 & 3 & 4 & 5 & 6 & 7 & 8 & 9 & 10 & 11 & 12 \\
\hline & & & & & & & & & & & \\
\hline
\end{tabular}

Table 7. Auditor's working document. Inspection of operations to obtain production stocks at the warehouse of PJSC "Dniprospetsstal"

\begin{tabular}{|c|c|c|c|c|c|c|c|c|c|c|c|}
\hline № & 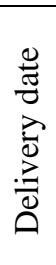 & 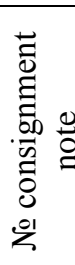 & 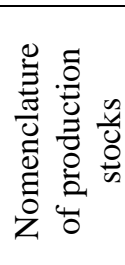 & 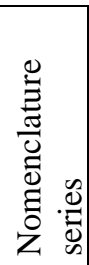 & 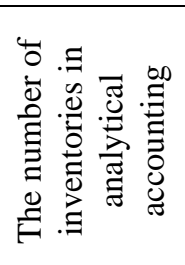 & 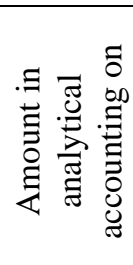 & 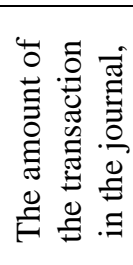 & 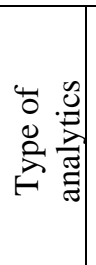 & 苞 & 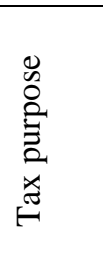 & 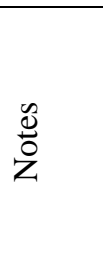 \\
\hline 1 & 2 & 3 & 4 & 5 & 6 & 7 & 8 & 9 & 10 & 11 & 12 \\
\hline
\end{tabular}

Table 8. Auditor's working document. Sampling of production stocks from the warehouse to the production of PJSC "Dniprospetsstal"

\begin{tabular}{|c|c|c|c|c|c|c|c|c|c|c|c|c|c|c|c|c|}
\hline \multicolumn{3}{|c|}{$\begin{array}{l}\text { The balance of } \\
\text { stocks in } \\
\text { production at } \\
\text { the beginning of } \\
\text { the month, tons }\end{array}$} & \multicolumn{4}{|c|}{$\begin{array}{l}\text { Received stocks in } \\
\text { production }\end{array}$} & \multicolumn{4}{|c|}{ Production stocks returned } & \multicolumn{3}{|c|}{$\begin{array}{l}\text { Balance of stocks at } \\
\text { the end of the month, } \\
\text { tons }\end{array}$} & \multicolumn{2}{|c|}{$\begin{array}{l}\text { Actual } \\
\text { consumption, } \\
\text { tone }\end{array}$} & \\
\hline 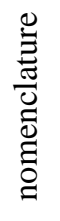 & 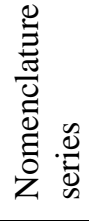 & 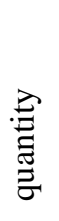 & 营 & 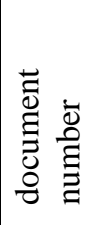 & 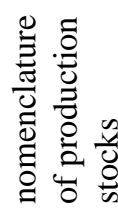 & 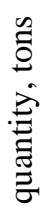 & 苞 & 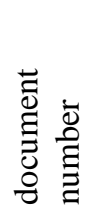 & 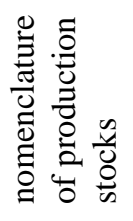 & 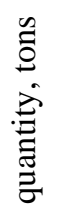 & 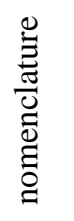 & 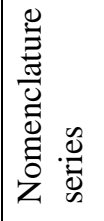 & 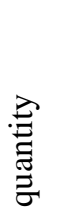 & 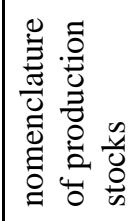 & 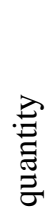 & 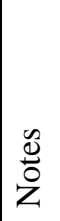 \\
\hline 1 & 2 & 3 & 4 & 5 & 6 & 7 & 8 & 9 & 10 & 11 & 12 & 13 & 14 & 15 & 10 & 17 \\
\hline & & & & & & & & & & & & & & & & \\
\hline
\end{tabular}


Table 9. Auditor's working document. Comparison of norms of writing off production stocks for production

\begin{tabular}{|c|c|c|c|c|c|}
\hline & $\begin{array}{c}\text { Nomenclature of } \\
\text { production stocks }\end{array}$ & $\begin{array}{c}\text { A series of } \\
\text { nomenclature of } \\
\text { production stocks }\end{array}$ & $\begin{array}{c}\text { Accounting } \\
\text { norm }\end{array}$ & \multicolumn{2}{|c|}{$\begin{array}{c}\text { Actual } \\
\text { norm }\end{array}$} \\
\end{tabular}

Table 10. Auditor's working document. The list of violations that were identified during the audit of inventories in warehouses

\begin{tabular}{|c|c|c|c|c|c|c|c|c|c|c|c|c|}
\hline \multirow[b]{2}{*}{$\frac{\frac{\pi}{0}}{\frac{\pi}{0}}$} & \multicolumn{3}{|c|}{ Document } & \multicolumn{4}{|c|}{ According to accounting } & \multicolumn{4}{|c|}{$\begin{array}{l}\text { According to } \\
\text { audit }\end{array}$} & \multirow[b]{2}{*}{$\frac{0}{.0}$} \\
\hline & 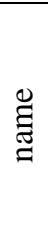 & 익 & 莺 & 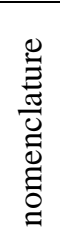 & 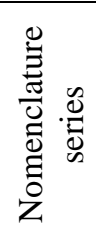 & 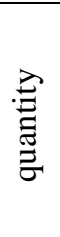 & 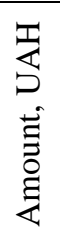 & 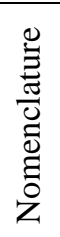 & 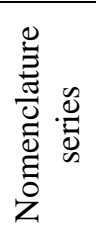 & 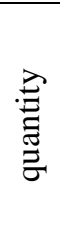 & 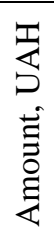 & \\
\hline 1 & 2 & 3 & 4 & 5 & 6 & 7 & 8 & 9 & 10 & 11 & 12 & 13 \\
\hline & & & & & & & & & & & & \\
\hline
\end{tabular}

\section{Conclusions}

Author has done the financial analysis of the performance of PJSC "Dniprospetsstal" on the basis of which it can be noted that despite the fact that some financial indicators have a positive dynamics of change, the company is unprofitable.

An algorithm for forming analytical accounting for additional properties of production stocks in the warehouses of PJSC "Dniprospetsstal" and information on the analysis of the availability of production stocks in the warehouse and cost estimation of the stock of production stocks in the nomenclature prices is proposed. All the above proposals for the formation of analytical accounting for additional properties of stocks and improve the documentation of the availability and receipt of production stocks make it possible to obtain more information from fewer documents, which, in turn, increases their informativeness and analyticalness.

According to the results of the research, the method of conducting an audit of inventory valuation in the warehouses of PJSC "Dniprospetsstal" and working documents of the auditor, which can be used at the enterprise to conduct a better audit of inventories.

\section{References}

1. Hamova O. V., Kozachok I. A., Marchenko. Udoskonalennya obliku vyrobnychykh zapasiv ta otsinka finansovoho stanu TOV «BZ ZBV» T.YU. Ashyfina. Investytsiyi: praktyka ta dosvid: naukovo-praktychnyy zhurnal[in Ukrainian].

2. Hamova O. V., Kozachok I. A. Formuvannya systemy obliku ta audytu stanu ta rukhu osnovnykh zasobiv na pidpryyemstvi Elektronne naukove fakhove vydannya «Efektyvna ekonomika». www.economy.com.ua, № 1, 2018 [in Ukrainian].

3. O.V. Hamova, L. K. Feofanov, YU. V. Rakytyans'ka. Shlyakhy vdoskonalennya obliku ta audytu vyrobnychykh zapasiv na skladakh PRAT «Dniprospetsstal» Investytsiyi: praktyka ta dosvid: naukovo-praktychnyy zhurnal.vypusk 3. 2020. 57-62 [in Ukrainian].

4. Kozachok I. A. Analiz ta kontrol' pokaznykiv vykorystannya finansovykh resursiv u systemi upravlinnya diyal'nistyu promyslovoho pidpryyemstva / I. A. Kozachok. - Visnyk Dnipropetros'koho universytetu. Seriya «Ekonomika» [in Ukrainian].

5. Kulakovs'ka L. P. Orhanizatsiya i metodyka audytu: navch. posibnyk L. P. Kulakovs'ka, YU.V. Picha-K.: Karavella, 2005. 560s. [in Ukrainian]. 